\title{
3-31-2015
}

\section{Focused ultrasound for treatment of bone tumours.}

Dario B. Rodrigues

Thomas Jefferson University

Paul R. Stauffer

Thomas Jefferson University

David Vrba

Czech Technical University in Prague

Mark Hurwitz, MD

Thomas Jefferson University and Hospitals

Follow this and additional works at: https://jdc.jefferson.edu/radoncfp

Part of the Oncology Commons, and the Radiology Commons

Let us know how access to this document benefits you

\section{Recommended Citation}

Rodrigues, Dario B.; Stauffer, Paul R.; Vrba, David; and Hurwitz, MD, Mark, "Focused ultrasound for treatment of bone tumours." (2015). Department of Radiation Oncology Faculty Papers.

Paper 68.

https://jdc.jefferson.edu/radoncfp/68

This Article is brought to you for free and open access by the Jefferson Digital Commons. The Jefferson Digital Commons is a service of Thomas Jefferson University's Center for Teaching and Learning (CTL). The Commons is a showcase for Jefferson books and journals, peer-reviewed scholarly publications, unique historical collections from the University archives, and teaching tools. The Jefferson Digital Commons allows researchers and interested readers anywhere in the world to learn about and keep up to date with Jefferson scholarship. This article has been accepted for inclusion in Department of Radiation Oncology Faculty Papers by an authorized administrator of the Jefferson Digital Commons. For more information, please contact: JeffersonDigitalCommons@jefferson.edu. 


\section{Focused ultrasound for treatment of bone tumors}

Dario B. Rodrigues ${ }^{1}$, Paul R. Stauffer ${ }^{1}$, David Vrba ${ }^{2}$ and Mark D. Hurwitz ${ }^{1}$

${ }^{1}$ Department of Radiation Oncology, Thomas Jefferson University, Philadelphia, PA, USA

${ }^{2}$ Department of Biomedical Technology, Czech Technical University in Prague, Prague, Czech Republic

Corresponding author:

Mark D. Hurwitz, MD

Radiation Oncology Department, Thomas Jefferson University Hospitals

Bodine Cancer Center Suite G-301, 111 S 11th St, Philadelphia PA 19107, USA

$\mathrm{T}:+1$ 215-955-6702 / F: +1 215-955-0412

E-mail: mark.hurwitz@ @ jefferson.edu

Running title: Focused ultrasound for treatment of bone tumors

Funding: N/A

Financial disclosures: MDH consultant, InSightec. 


\section{ABSTRACT}

Purpose: Focused ultrasound (FUS) is a modality with rapidly expanding applications across Medicine. Treatment of bone lesions with FUS including both benign and malignant tumors has been an active area of investigation. Recently, as a result of a successful phase III trial, magnetic resonance guided FUS is now a standardized option for treatment of painful bone metastases. This report reviews the clinical applications amenable to treatment with FUS and provides background on FUS and image guidance techniques, results of clinical studies, and future directions.

Methods: A comprehensive literature search and review of abstracts presented at the recently completed $4^{\text {th }}$ International Focused Ultrasound Symposium was performed. Case reports and older publications revisited in more recent studies were excluded. For clinical studies that extend beyond bone tumors, only the data regarding bone tumors are presented.

Results: Fifteen studies assessing the use of focused ultrasound in treatment of primary benign bone tumors, primary malignant tumors, and metastastic tumors meeting the search criteria were identified. For these clinical studies the responders group varied within $91-100 \%, 85-87 \%$ and $64-94 \%$, respectively. Major complications were reported in the ranges $0 \%, 0-28 \%$ and $0-4 \%$ for primary benign, malignant and metastatic tumors, respectively.

Conclusions: Image-guided FUS is both safe and effective in the treatment of primary and secondary tumors. Additional phase III trials are warranted to more fully define the role of FUS in treatment of both benign and malignant bone tumors.

Keywords: High-Intensity Focused Ultrasound, Ablation, Bone tumor, Pain palliation, Image guidance. 


\section{INTRODUCTION}

Bone tumors, whether benign or malignant, often present challenges with local disease control and pain. Several bone tumor clinical studies have been conducted in the last decade, focused on both curative and palliative treatments. One emerging modality in treatment of bone tumors is high intensity focused ultrasound (FUS), which causes thermal damage of tissue using focused sound waves. The FUS treatment is guided in real-time by magnetic resonance (MRgFUS) or ultrasonography (USgFUS), which provides a feedback mechanism to increase treatment accuracy. This technique is non-invasive and does not use ionizing radiation, which contrasts with standard approaches, such as surgery or radiotherapy, used in cancer treatment. The aim of this paper is to review bone tumor clinical studies using both USgFUS and MRgFUS, including benign tumors, primary malignancies, and metastatic bone tumors.

The vast majority of primary bone tumors are benign. Many are asymptomatic and thus remain undetected until radiographic examinations are performed for other reasons. Thus, the actual incidence of benign bone tumors is currently indeterminate [1]. One of the most common is osteoid osteoma, comprising nearly $10 \%$ of benign bone tumors [2]. It consists of a nidus, or core of growing cells, surrounded by a thick bony shell that is normally found in the appendicular skeleton [3]. They are predominantly seen in children, teenagers, and young adults, with more than $80 \%$ of tumors seen in individuals between the ages of 5 and 30 years [4]. The presence of a benign bone lesion does not necessarily mean lack of aggressiveness; histologically benign lesions may be locally highly aggressive, causing severe discomfort and pain [5].

Malignant primary bone tumors constitute $0.2 \%$ of all malignancies in adults and approximately $5 \%$ of childhood malignancies [1]. The most common primary malignant bone tumor is osteosarcoma, representing $35 \%$ of total primary bone malignancies [6]. The 5-year overall 
survival rate for bone sarcoma is $68 \%$. Osteosarcomas usually develop in areas where the bone is growing quickly, such as near the ends of the long bones, and are most common in children and young adults. These particular tumors require aggressive local treatment and at times may require amputation.

Bone metastases are the most common source of pain in cancer patients [7]. Autopsy studies have shown that up to $85 \%$ of patients with breast, prostate and lung cancer have bone metastases at the time of death. Complications due to skeletal metastases, including intractable pain, fracture, and decreased mobility, can dramatically reduce performance and quality of life and lead to depression and anxiety [8]. Bone metastases portend a poor prognosis, with patients generally facing a median survival of 3 years or less. In lung cancer, survival is typically measured in months, whereas patients with breast cancer or prostate cancer often live for several years. Bone metastases are generally classified as osteolytic which is characterized by destruction of normal bone or osteoblastic characterized by deposition of new bone. This distinction is not absolute since metastatic lesions can contain both osteolytic and osteoblastic components [9].

There are two distinct treatment approaches for bone tumors: curative and palliative. For thermal ablation techniques, in particular, curative treatment aims for complete coagulation necrosis of the primary lesion. In palliative treatment of primary or secondary bone tumors, therapeutic goals include pain palliation, tumor reduction, prevention of impending pathologic fractures, and/or tumor decompression. The denervation of the periosteum, which contains pain-reporting nerve fibers, is considered a major factor in pain palliation. This explains the rapid relief following ultrasound treatment which is characterized by enhanced power deposition in bone relative to surrounding soft tissues [10]. 
Clinical applications of thermal ablation therapy are expanding rapidly due to the ability to produce immediate obliteration of either small tumors or benign disease, when the target volume is located in an anatomic region with sufficient biological reserve and/or separation from surrounding critical normal tissues. Either cryogenic temperatures $\left(<-40^{\circ} \mathrm{C}\right)$ or high temperatures $>50-60^{\circ} \mathrm{C}$ produce complete ablation of the tissue vasculature and most importantly disrupt and coagulate all structural proteins in the target cells. These effects are non-subtle and irreversible, leading to immediate and complete cellular death. In lower dose regions, in the transition zone of a thermally coagulated lesion, there is a percentage of cells that survive the thermal insult. In this border region, adjunctive therapies such as radiation or chemotherapy may be helpful in further expanding the radial penetration of effective therapy, by providing some differential effect on weaker tumor cells relative to the surrounding normal tissue host.

There are numerous technologies available to produce a high intensity heat focus at depth in tissue. Invasive approaches include interstitial or intracavitary placement of radiofrequency (RFA), microwave (MWA), laser, or thermal conduction sources into the target region (Table I). These implantable heat sources are well-characterized in the literature [11-14], and for many tissue sites like liver, breast, prostate, kidney and lung, they can heat deep tissue targets effectively without unacceptable normal tissue complications $[4,15]$. Insertion of heat sources directly into bone tissue is difficult however, such that a non-invasive approach with precise control of the focal zone at depth is required. Taking advantage of the short wavelength and deep penetration of ultrasound pressure waves, beams may be combined from large external transducer arrays to produce an intense focal hot spot at depth non-invasively; thus the name high intensity focused ultrasound (FUS). 


\section{METHODS}

This section reviews the FUS method, image guidance techniques, and FUS devices used in ongoing clinical studies. Furthermore, we address primary and secondary endpoints typical in the analyzed clinical studies as well as the tools for outcome assessment.

\subsection{High-Intensity Focused Ultrasound}

In general, ultrasound systems produce an acoustic pressure wave from one or more piezoelectric transducers that operate at a frequency in the range of $0.2-4 \mathrm{MHz}$. Attenuation of ultrasound energy as it propagates through biologic tissue results in a rise of temperature in the treated volume. Coagulative necrosis and cell death occur within seconds at temperatures in the range of $65-85^{\circ} \mathrm{C}[16]$, so that the ablative treatment must be well localized to the tumor target and avoid surrounding normal tissues. To achieve the required focusing and rapid elevation of tissue temperature at depth, the ultrasound energy is usually intensified at a focal spot by using multiple intersecting ultrasound beams that converge on the target. Typical clinical focused ultrasound systems produce high intensity focal volumes of $0.2-20 \mathrm{~mm}^{3}$ at depth, while spreading out the ultrasound energy over a large surface area under the transducer array so as to have negligible effect on tissues outside the focus. Because of the high temperatures achieved in the high intensity focus, sonications are generally limited in duration to only a few seconds. This reduces the potentially detrimental thermal smearing and energy dissipation effects to surrounding tissue due to blood perfusion. Because of these technical issues, ablation of a typical tumor requires sequential tiling of multiple sonications to create homogeneous thermal damage and coagulative necrosis of the entire target volume $[16,17]$.

With focused ultrasound systems, tissue in the path of the ultrasound beams outside the focus is warmed, but only to sub-lethal temperatures. Between successive sonications, the heat deposited 
in intervening tissue is dissipated by normal tissue conduction and perfusion cooling effects [18].

Due to the low thermal conductivity and high ultrasound attenuation in the periosteum and bone cortex, it is possible to use lower energy levels when treating bone compared to treatment of well-perfused soft tissue. This provides an improved safety profile by reducing thermal damage around the treated bone site [19-21].

\subsubsection{Image-guided FUS}

Over the past decades, there have been numerous external ultrasound array systems for focused heating in the body, [22-27] including one system specifically optimized for small animal treatments [28]. At present, there are three commercial non-invasive ultrasound heating systems that have been integrated within either US or MR imaging systems for image-guidance of FUS treatments in humans: the ExAblate system (InSightec Ltd., Tirat Carmel, Israel) based on the General Electric MR platform [29, 30]; the Sonalleve FUS system (Koninklijke Philips Electronics NV, Eindhoven, The Netherlands) based on the Phillips MR platform [31, 32]; and the Haifu system (Model JC, Chongqing Haifu Medical Technology Co. Ltd., Chongqing, China) coupled with a B-type ultrasonography system [33].

In USgFUS, the US imaging probe is situated in the center of therapeutic transducer array and provides real-time sonography feedback. This way, the user can target the lesion to be treated, guide the US energy deposition, and assess the extent of acute coagulation necrosis in the treated tissue $[19,33,34]$. MRI adds to focused ultrasound therapy the advantages of high resolution lesion localization, real time temperature monitoring, and post-treatment tissue evaluation. Lesion visualization is achieved through the intrinsic high tissue contrast of MRI, while temperature monitoring is achieved through use of specific MRI sequences (proton resonance frequency shift method - PRF) performed during the ablation [17]. 


\subsection{Clinical studies}

This review summarizes clinical studies to date assessing use of therapeutic ultrasound for bone tumors, including both benign and malignant primary lesions, as well as metastatic disease. Case reports were excluded from analysis. In instances of published updates of previous studies, only the more complete publications were analyzed. For clinical studies that extend beyond bone tumors, only the data regarding bone tumors are presented [34, 35]. The 4th Focused Ultrasound Symposium (October 12-16, 2014 in North Bethesda, Maryland USA) reported significant advances in the FUS treatment of bone tumors, and abstracts from that recent meeting were considered under the aforementioned inclusion criteria. The following sections summarize the most relevant aspects of clinical trial design: inclusion criteria for patient selection, endpoints, and instruments for outcome assessment.

\subsubsection{Inclusion criteria for patient selection}

For safe and effective ablation therapy, carefully defined patient selection criteria are critically important. The anatomy of the human skeleton necessarily involves many critical neighboring structures. Patients with bone tumors in difficult to access locations or in close proximity to major nerves, e.g. spinal tumors, have been typically excluded from clinical studies. Some studies also excluded patients with tumors that are: larger than $10 \mathrm{~cm} \mathrm{[19],} \mathrm{close} \mathrm{to} \mathrm{the} \mathrm{joints}$ [36], close to blood vessels [33], in weight-bearing bones [18, 20], or with locally advanced disease [35].

Patients with bone metastases were included in published studies only if they reported moderate or severe pain, typically a score of 4 or greater out of 10 for worst pain in a 24-hour period. Furthermore, patients with more than 1-2 metastatic sites were excluded since this type of pain is believed to be better treated with a systemic rather than focal approach [4]. In the case of 
MRgFUS, MR compatibility must be considered and patients with claustrophobia or pacemakers were excluded from this image guidance technique. Some studies aimed for primary treatment, so patients with previous radiotherapy were excluded [37].

The Karnofsky Performance Status Scale is widely used to quantify the functional status of cancer patients [38]. One study in particular did not consider patients with a Karnofsky score lower than $70 \%$ [19]. Finally, some patients were enrolled only if there was no other treatment technique available or feasible [18-21, 33, 35].

\subsubsection{Endpoints and instruments for outcome assessment}

The primary endpoints of a clinical study are typically safety (Phase I) and efficacy (Phases II and III). Safety is assessed by occurrence of adverse events, which can be divided into minor and major complications [39]. The definition of efficacy is dependent on the type of tumor and intent of treatment. For primary bone tumors, either malignant or benign, efficacy is analyzed in terms of local tumor control, survival, recurrence, and/or conservation of the diseased-limb. On the other hand, treatments for bone metastases aim for pain palliation and improved quality of life; where quality of life is considered a secondary endpoint. Geiger et al. also distinguish technical and clinical endpoints [17]. The technical endpoints address short-term complications from the FUS procedure, and will be considered under the umbrella of safety. In palliative treatments, pain progression is also considered.

Different instruments were used to quantify each target outcome, including questionnaires for pain and quality of life assessment, as well as anatomical imaging (CT, MRI, or CE-MRI), functional imaging (PET/CT, SPECT, or scintigraphy), biochemical (e.g. alkaline phosphatase) and histopathology analyses for determination of response. Each clinical study used one or more of these instruments to evaluate clinical outcome. 


\section{Safety}

The safety endpoint is evaluated in terms of incidence and severity of complications due to the FUS treatment. These adverse events must be assessed by clinical and imaging examinations, where the latter are especially relevant to detect occult adverse events. Some authors (e.g. [19]) subdivide this endpoint into minor and major complications, where the latter are events that lead to substantial morbidity, disability, increased level of care, or results in hospital admission or substantially lengthened hospital stay [40]. We standardized this classification for all studies.

\section{Local tumor control}

Local tumor control is generally accessed via imaging (SPECT, MRI or PET/CT), and may also be assessed with biochemistry and histopathology analysis. Several parameters can be analyzed: inflammatory status; bone remodeling and/or remineralization; tumor vascularity and perfusion; tumor cellular survival and activity; coagulative necrosis of the target area, and particularly tumor size. For primary malignant bone tumors, the presence and condition of metastatic lesions are also evaluated, e.g., using chest radiography and/or CT to define lung metastases [19]. Furthermore, biochemical markers for cancer are also assessed in all clinical studies that address primary malignancies $[19,33,34]$. To evaluate treatment efficacy via local tumor control, lesion changes were evaluated by Napoli et al. [37] in accordance with the MD Anderson (MDA) criteria [41]. These criteria include quantitative and qualitative assessments of the behavior of bone metastases. The response is divided into four categories: complete response (CR), partial response (PR), progressive disease (PD), and stable disease (SD). Quantitatively, these criteria define PR as a decrease of $50 \%$ or more in the sum of the perpendicular measurements of a lesion and PD as an increase of $25 \%$ or more in this sum. 


\section{Pain palliation}

Patient response to treatment was measured by using the Brief Pain Inventory (BPI), a validated numeric scale for the evaluation of pain in cancer patients [42]. In this evaluation, patients were asked to rate their worst pain with allowed responses ranging typically from a score of 0 to 10 ( 0 $=$ no pain, $10=$ pain as bad as you can imagine). Two different names were used for this 11-point scale: numerical rating scale (NRS) and visual analog scale (VAS). Geiger et al. [17] also used the terminology VAS, but for a 1-10 range. Finally, Li et al. [33] used a 4-point pain scale (0-3) named verbal rating scale (VRS).

Another assessment of palliative therapy is derived from pre- and post-procedural pain as defined by the use analgesics [40]. In order to quantify its use, a morphine equivalent daily dose (MEDD) intake form was used in some studies [43]. In the case of metastatic tumors, both pain scales and MEDD followed the standards published by the International Bone Metastases Consensus Working Party (IBMCWP) [44]. This consensus defines a minimum follow-up of 2 weeks, 1 month, and then monthly until 6 months after delivery of FUS treatment. Longer follow-up is considered for patients with prolonged survival. Complete response is defined as a pain score of zero (VAS or NRS) at the treated site with no concomitant increase in analgesic intake (stable or reducing analgesics in daily oral morphine equivalents). Partial response is defined as any of the following: (i) pain reduction of 2 or more at the treated site on a $0-10$ scale without analgesic increase; (ii) analgesic reduction of $25 \%$ or more from baseline without an increase in pain. Pain progression is defined as an increase in the pain score of 2 or more points above baseline at the treated site with stable analgesic use, or an increase of $25 \%$ or more in daily oral morphine equivalent compared to baseline with the pain score stable or 1 point above baseline [44]. 
One study [36] did not account for the interference of analgesics in pain, but similarly to IMBCWP guidelines, considered a minimum VAS reduction of 3 points to be clinically significant. Another study proposed their own guidelines for treatment response based on guidance from World Health Organization standard [33].

\section{Quality of life}

Quality of life (QoL) is considered an important secondary endpoint in the majority of clinical studies that address painful bone metastases. Pain interference with daily living is evaluated on a 0 -10 scale $(0=$ no interference, $10=$ completely interferes $)$ with questions concerning general activity, mood, ability to walk and work normally, relations with other people, sleep, and enjoyment of life [4]. This assessment of functional interference related to pain was monitored using different questionnaires. The first is described in the brief pain inventory (BPI-QoL) [42] and the second (QLQ- BM22) was developed by the European Organization for Research and Treatment of Cancer [45]. 


\section{RESULTS}

The summary of all clinical studies meeting the above criteria is presented in Tables II, III and IV for primary benign, primary malignant and metastatic bone tumors, respectively. Based on the search criteria, 15 clinical studies were selected, which included both USgFUS and MRgFUS treatments. The average treatment time was 2 hours, ranging from 2 minutes [35] up to $18 \mathrm{~h}$ [19]. The procedure time was in part dependent on the type of anesthesia or conscious sedation, but also on tumor size and blood supply. The number of treatments per site varied: the majority being a single treatment and occasionally 2 treatments for both benign tumors and metastatic tumors. Primary malignant tumors required up to 7 sessions $[19,33,46]$. Details on treatment planning of image-guided FUS are outside the scope of this review, and can be found elsewhere for MRgFUS [16] and USgFUS [33].

\subsection{Primary benign bone tumors}

In 2013, Napoli et al. reported on the use of MRgFUS to treat six patients with limited joint function and reduced quality of life due to painful osteoid lesions [47]. These patients were included in a recent 24 month follow-up, which included a total of 29 patients with osteoid osteoma [17, 48]. Patients received therapy using MRgFUS, delivered toward the nidus, identified on MRI and/or CT. The treatment was well tolerated and no adverse events were recorded with follow-up up to 24 months. Complete clinical response occurred in 27/29 patients as defined by absence of pain and no intake of analgesics. VAS decreased dramatically in these patients: from 7.9 at baseline to 0.7 on average at the last follow-up (12-24 months). Two patients reported pain recurrence with average VAS $=5$ requiring subsequent CT-guided radiofrequency ablation. Imaging evaluation with CE-MRI demonstrated edema and hyperemia decrease in every lesion associated with complete response. At CT, bone remodeling was evident in all complete 
responders, and nidus fading was demonstrated in 15/27 patients. No complications were observed.

Arrigoni and his colleagues [49] treated 12 painful epiphyseal benign bone lesions with MRgFUS. After the treatment, 11 patients had pain regression with a mean VAS that decreased from 7.8 to 2.1 on average, 12 months after treatment. A patient with periosteal chondroma did not experience improvement. With 12 month follow-up, 8 patients did not show any signs of edema on MRI. No substantial changes were found in CT images, but in 3 cases they observed a recovery of the normal morphological structure of bone. No major complications were observed.

From March 2013 to May 2014, 7 consecutive patients with superficial osteoid osteomas of the lower limb were treated with MRgFUS [50]. The mean VAS at the baseline was 7.5. In all patients VAS dropped to 0 after 1 month. In 6 patients VAS remained at 0 during the follow-up, while in 1 patient VAS dropped from 9 to 0 after 1 month, but rose to 2 after 3 months (6-month control available, no recurrence documented). No adverse events were observed.

\subsection{Primary malignant bone tumors}

The first FUS treatment performed in bone was in China, in a tibial osteosarcoma on December 1997. Through October 2001, a total of 1038 patients with solid tumors had undergone extracorporeal USgFUS ablation in 10 Chinese hospitals. 153 were bone tumors and 44 were reported [34]. Among them, FUS was performed as a limb-salvage treatment in combination with neoadjuvant chemotherapy in 34 patients (Enneking's stage IIb). The remaining ten patients were stage IIIb (nine patients with lung metastasis) and were treated with FUS alone with palliative intent. Histopathological examination demonstrated clear evidence of tumor destruction and regrowth of normal bone in the treated region. Follow-up diagnostic imaging revealed that there was no, or reduced, blood supply, and no uptake of radioisotope in the FUS treated tumor, both 
indicating a positive therapeutic response and absence of viable tumor (no response rate available). Furthermore, both CE-MRI and bone scans indicated complete coagulation necrosis of the treated tumors. At 6-12 month follow-up, imaging showed obvious regression of the lesion and the region of induced coagulation necrosis. Most frequently, the nonenhancing treated volume decreased by less than $20-50 \%$ in volume. The follow-up range was $10-40$ months, and the overall survival rate was $85 \%$ (38/44). One patient with stage IIb disease, and five patients with stage IIIb disease died as a result of distant metastases. Five patients underwent amputation due to local recurrence. Few major complications were observed during follow-up period (8\%), including pathological fractures in three patients, peripheral nerve damage in two, restricted joint movement in one, and epiphyseal separation in another one.

Li et al. evaluated 13 patients diagnosed with primary bone tumors, primarily osteosarcomas, treated with USgFUS [33]. At a 6 month follow-up, PET/CT and SPECT showed no abnormal radioactivity concentrations in the tumor areas; the areas became cold lesions of the size and shape of the original bone tumor. The pain was quantified in a scale ranging from $0-3$, and decreased, on average, from 1.85 at baseline to 0.08 at the follow-up. The response rate for patients with primary bone tumors was significant: 6 (46\%) patients had CR, 5 (38\%) had PR, 1 $(8 \%)$ had moderate response, and $1(8 \%)$ had PD. The overall response rate was $85 \%$. The 1-, 2-, 3-, and 5-year overall survival rates were 100\%, 85\%, 69\%, and 39\%, respectively. No abnormalities in electrocardiogram, liver, and kidney functions and blood electrolytes were detected. After two months, alkaline phosphatase and lactic acid dehydrogenase returned to normal levels [33].

In 2010, Chen et al. reported long-term follow-up results of a non-randomized clinical trial [19]. The group used USgFUS for the treatment of 80 primary malignant tumors, including 60 stage IIb and 20 stage IIIb (Enneking staging) patients. FUS combined with chemotherapy was 
performed in 62 patients with osteosarcoma, 1 with periosteal osteosarcoma and 3 with Ewing's sarcoma. The remaining 14 patients with chondrosarcoma, malignant giant cell tumor of bone, sarcoma of the periosteum or with unknown histology received FUS alone. Follow-up images demonstrated complete ablation of the tumors in 69 patients and greater than 50\% tumor ablation in the remaining 11 patients. The overall 5-year survival rate was 51\%, with $64 \%$ and $16 \%$ for patients with stage IIb and III disease, respectively. Among the patients with stage IIb disease, long-term survival rates were substantially improved in 30 patients that received combined treatment with FUS and chemotherapy (86\% 5-year survival rate), in comparison with the survival rates for 24 patients that did not finish chemotherapy and six patients who underwent partial ablation only (36\% 5-year survival rate). Only five of the 69 patients who underwent complete ablation had local cancer recurrence during the follow-up period (5-87 months). All patients experienced mild pain and among other adverse events, $28 \%$ were major complications [39], where 11 of these patients required surgery and 8 presented severe peripheral nerve damage. In these cases, the distance between the damaged nerves and the tumor margin was less than 10 $\mathrm{mm}$, suggesting that $10 \mathrm{~mm}$ is a reasonable safety margin to avoid nerve damage in FUS treatments.

The most recent USgFUS malignant bone tumor treatment series reported in literature was in 2013, by Wang et al. [46]. Eleven patients with primary malignant tumors of the bony pelvis received USgFUS for both palliative (7 patients) and curative purposes (4 patients). The efficacy of FUS ablation was only assessed by CE-MRI. With median follow-up of 22 months (11-154 months), seven patients that received palliative ablation died of metastatic disease. Enlargement of residual tumor was observed in all patients receiving palliative FUS ablations 6-24 months after study entry. The remaining four patients that received ablation with curative intent were alive at the time of the publication. Local recurrence was observed in one patient receiving 
curative FUS ablation, which was retreated by additional FUS ablation; no local recurrence was observed thereafter. Significant coagulative necrosis was obtained in all patients, with an average volume ablation ratio of $87 \%$ (range $65-100 \%$ ). Complete tumor necrosis was achieved in all patients receiving curative FUS ablation. No major complications were encountered.

\subsection{Metastatic bone tumors}

Liberman et al. in 2009 published the first multicenter clinical study on the use of FUS for pain palliation of bone metastases [21]. This report includes previous pioneer work from [18] and [20], comprising 31 patients and 32 bone lesions. 3-month follow-up was available for 25 out of 31 patients. Eighteen patients (72\%) had a significant reduction in pain (>2 points) and $9(36 \%)$ reported a VAS score of 0 . The average VAS score decreased from 5.9 prior to treatment to 1.8 at the 3-month follow-up; with $52 \%$ of patients reporting substantial pain relief within 3 days. Twenty-four percent had no response and one patient (4\%) experienced worsened pain levels. A reduction in opioid usage was reported in $67 \%$ of patients with recorded medication data. No major complications were reported.

Li et al. also reported on 12 patients with bone metastases treated with USgFUS [33]. 96\% of the patients suffered pain before the procedure. Pain decreased from 1.75 at baseline to 0.17 on a $0-3$ scale at the last follow-up (4-6 months). Response rates were classified by MRI or PET/CT and not pathologically: $5(42 \%)$ complete response, $4(33 \%)$ partial response, $1(8 \%)$ had progressive disease, with the overall response rate as 75\%. The 1-, 2-, 3-, and 5-year overall survival rates were $83 \%, 17 \%, 0 \%$, and $0 \%$, respectively.

Napoli et al., in 2013, reported a prospective, single-arm research study with 18 patients treated with MRgFUS for painful bone metastases [37]. The pain severity score changed significantly from a baseline average of 7.1 to 1.1 at 3-month follow-up. A score of 0 for pain severity, 
without medication intake, was reported by $13 / 18$ patients (72\%) at final follow-up, consistent with a complete response to treatment. CT examinations demonstrated increased bone density with restoration of cortical borders in 5/18 patients (28\%). According to the MDA criteria [41], a complete response to treatment was observed in $2 / 18$ patients (11\%), a partial response in $4 / 18$ patients (22\%), stable disease in 10/18 patients (56\%) and progressive disease in 2/18 patients (11\%). No treatment-related adverse events were recorded during the study.

The results of the first phase III clinical trial on bone tumors were published in 2014 by Hurwitz et al. [43]. 147 patients with metastatic bone pain, typically refractory to radiation and other pain interventions, were randomized to MRgFUS treatment or placebo treatment. Patients randomized to placebo underwent the same procedure as those receiving MRgFUS treatment but without energy deposition. The pain response rates three months after treatment were $64 \%$ in the MRgFUS treated arm versus $20 \%$ in the placebo arm. Complete pain relief was observed in $23 \%$ of treated patients, compared to $6 \%$ of patients who received placebo treatment. Approximately two-thirds of responders experienced significant pain relief - as defined as a decrease in worst NRS score by 2 points or more - within three days of treatment, establishing the ability of MRgFUS to induce fast pain response. This response was accompanied by a similarly rapid improvement in patient function scores. The most common complication was pain during MRgFUS treatment (32\%) and major complications (third degree skin burn, fracture) occurred in $4 \%$ of treated patients. However, one fracture was outside the treated area, and the skin burn was due to a violation on the inclusion criteria protocol. Furthermore, the majority of adverse events $(60 \%)$ were transient and resolved on the treatment day and 51 patients $(46 \%)$ had no adverse events.

In 2014, Huisman and colleagues reported the first experience with volumetric MRgFUS for palliative treatment of painful bone metastases [51]. In this technique, the focal spot is iteratively 
switched to well-separated positions around a circular trajectory and sonications are repeated continuously till ablative temperatures are achieved throughout increasing diameter concentric circles. The resulting volumetric temperature rise contrasts with more traditional raster scan iterative sonications where each overlapping focal ablation is followed by a cooling period. The goal is improvement in ablation zone homogeneity, energy efficiency, and overall treatment time [52]. Pain inventories were implemented at 3 days and 1 month after treatment for 11 patients. At 3 days after volumetric MR-FUS ablation, NRS pain scores decreased significantly from 8 to 6 on average, and a response was observed in a 6/11 patients (55\%). At 1-month follow-up, 9 evaluable patients had NRS pain scores decreased significantly compared to baseline from 8 to 4 on average and 6/9 patients obtained pain response. The overall response rate was $67 \%$ with $0 \%$ pain recurrence at 1-month follow-up. No treatment-related major complications were observed. The phase III trial as reported by Hurwitz et al. was subject recently to a retrospective analysis of the safety of combination MRgFUS with active systemic chemotherapy [53]. Chemotherapy data were available for 104 patients. Patients were followed for 3 months. Ninety patients were treated without chemotherapy, and fourteen were treated with chemotherapy. There was no significant difference between the response rates of the chemotherapy group (71\%) and the nonchemotherapy group (68\%). The overall adverse event rates were 57\% for chemotherapy patients and $45 \%$ for non-chemotherapy patients. Sonication pain was not significantly different between the groups, with $50 \%$ pain in the chemotherapy group and $28 \%$ pain in the non-chemotherapy group. Remaining adverse event rates were not significantly different $(\mathrm{p}=0.17)$.

A prospective, single arm, multicenter study was performed to evaluate the efficacy of MRgFUS for pain palliation of bone metastasis in patients who had exhausted radiotherapy or refused other therapeutic options [54]. 72 patients with painful bone metastases were enrolled. 34/72 patients (47\%) reported complete response to treatment and discontinued medications. 29/72 patients 
(40\%) experienced a pain score reduction $>2$ points, consistent with partial response. The remaining 9 patients (13\%) had recurrence after treatment. Significant differences between baseline (6) and follow-up (2) average VAS values and medication intake were observed. Similarly, a significant difference was found for QLQ-BM22 between baseline and follow-up $(\mathrm{p}<0.05)$. No treatment-related adverse events were recorded.

Finally, Bazzocchi et al. evaluated the clinical outcome of 39 patients (57 lesions) with painful bone metastases that were treated with MRgFUS [55]. Nine patients had a single bone metastasis, while 5 of them showed no other distant metastasis. The follow-up schedule included 1-, 3-, 6-, and 12-month evaluations. Forty-five lesions were evaluated after 1 month, while 31 lesions reached the 3-month (54\%), 17 the 6-month (30\%) and 8 the 12-month (14\%) follow-up point. Four patients died during follow-up and 3 lesions required retreatment. On a lesion-based approach, average VAS score at baseline was 5.2 decreasing to 2.5 at 1 month, and to 2.0, 2.1, and 1.2 after 3, 6 and 12 months respectively. In 14/45 lesions (31\%) the VAS dropped to 0 one month after the treatment; VAS persisted at the 0 level in 8 patients up to 3 months, in 5 patients up to 6 months, and in 3 patients up to 12 months. The major determinant of MRgFUS success was lesion size, with smaller lesions corresponding to higher efficacy in terms of pain relief possibly due to more efficient tumor debulking. Two treatment-related adverse events were reported: a single case of small skin burn, and one case of prostate inflammation in a patient treated to the ichiopubic ramus. 


\section{DISCUSSION}

The use of image-guided FUS has increased significantly in the past decade. The ability to deliver treatments accurately and non-invasively is a great advantage of image-guided FUS for the treatment of bone tumors. Contrary to ionizing radiation, image-guided FUS treatments can be repeated without the risk of cumulative dose effects in normal tissues outside the target. Also, thermal dose may be confined precisely to a small treatment volume (typically $0.2-20 \mathrm{~mm}^{3}$ ) without the need for invasive implants like microwave, radiofrequency, laser, and cryoablation techniques (Table I). Furthermore, the extent of treatment is readily controlled in three dimensions, which provides safe non-invasive conformal treatments that spare healthy tissue.

\section{Efficacy}

Standardization of validated assessment instruments facilitates comparisons of clinical studies. In this respect, the IBMCWP guidelines are seeing increasing use for evaluation of palliative treatments, which allows direct comparison of treatment outcomes. However, not all studies followed the same criteria, making comparison more challenging. For instance, Geiger et al. (2014) used a 10-point pain scale (1-10), Li et al. (2010) a 4-point pain scale (0-3), while the remaining studies used the IBMCWP 11-point pain scale (0-10). In the case of curative treatments, there are greater challenges comparing different studies since the number of patients varied widely and different endpoints were reported such as imaging, biochemical analyses, and survival rates. Taking into account overall response inclusive of complete and partial responses as a baseline for comparisons, the responders group varied within $92-100 \%, 85-87 \%$ and $64-87 \%$ for primary benign, primary malignant, and metastatic tumors, respectively. In treatments with a curative aim the recurrence rate was $0-14 \%$, and in palliative treatments the pain progression was 
$0-13 \%$. These results demonstrate the efficacy of FUS for both palliative and curative purposes in the treatment of bone tumors.

\section{Safety}

Similar to response, challenges exist in assessing safety across studies. Different studies used different classifications for adverse events. Therefore, for summary purposes we defined adverse events according to minor and major complications [39]. Overall, studies of benign tumors reported $0-66 \%$ minor and $0 \%$ major complications. Patients treated for primary malignant tumors presented higher complication ranges: $45-100 \%$ minor and 0-28\% major complications. Finally, patients with metastatic tumors presented complication ranges similar to the first group: 0-51\% minor and 0-4\% major complications. The most frequently observed complications were mild skin burn - usually resolving by one-two weeks after FUS - and sonication pain during treatment. Several authors inferred that skin burns were most likely due to lack of operator experience or not following established protocols. The lack of adverse events in some studies [17, $37,47,48,50,54,55]$ may relate to the limited number of patients. In clinical studies with large number of patients, an USgFUS study [19] reported a major complication rate of 28\% (22/80) for patients with primary malignant tumors. This was in large part due to lack of guidelines to protect normal structures, e.g. there were 8 serious nerve injuries as treatment guidelines did not limit proximity to nerves. Other primary malignant studies implemented a $1 \mathrm{~cm}$ tumor margin limit and major complications were limited to $8 \%$. On the other hand, MRgFUS produced only $4 \%$ (4/112) major complications in patients with bone metastases. Overall, the data provides strong evidence that FUS is safe for treatment of bone metastases and primary benign lesions, while other applications are still under investigation.

Sonication pain was the most common complaint during conscious sedation or epidural anesthesia. General anesthesia provides an advantage in terms of alleviation of sonication pain. 
Also, it ensures intraoperative immobilization which facilitates ultrasound targeting. However, the use of anesthesia does not allow patient feedback on pain and that could risk serious normal tissue damage [33]. As such, the optimization of patient anesthesia relative to complication rates requires further investigation, especially in treatment sites near critical tissue structures.

\section{US vs MR guidance}

Both MR and US imaging have been used to guide FUS in the treatment of bone tumors. Both imaging methods have advantages and disadvantages. Ultrasound imaging devices are less expensive, widely available, capable of real-time visualization, and clinically proven in the treatment of organs such as liver and kidney which move with respiration. The main disadvantage of US is poorer imaging resolution than MRI, especially in areas that have air or bone. Furthermore, nerves cannot be visualized by ultrasound imaging, and are thus difficult to avoid in the beam path. This is especially relevant because nerves are sensitive to ultrasonic energy and tumors are often located adjacent to nerves.

MRI can provide three-dimensional imaging with better resolution, which allows accurate tumor delineation. Also, MR allows continuous monitoring of temperature distribution within the treatment zone and thus measures both normal and target tissue temperature rise during FUS exposure. Since rapid protein denaturation occurs above $60^{\circ} \mathrm{C}$, sonications lead quickly to coagulative necrosis which is readily imaged by MR. The combination of these features - high resolution pre-treatment target visualization, MR thermometry during treatment to spare adjacent healthy tissue, and immediate post-treatment verification of effective treatment zone - makes MR guidance a highly attractive component of focused ultrasound therapy.

Despite the advantages, MR adds high cost, long treatment time, and problems in tracking moving targets, e.g. ribs, which may limit application of MRgFUS. MR temperature imaging is limited primarily to the soft tissues adjacent to bone since the PRFS method does not work well 
to calculate temperature rise in low water content bone cortex, bone marrow and fat tissue. However, the received thermal feedback is sufficient to allow control of actual sonication location and minimization of damage to non-target tissues [21]. This approach affords the treating physician a 'closed loop' monitoring of the treatment in real time, resulting in a high level of safety and efficacy [18]. Also, the reduced major complications associated with MRgFUS will reduce the overall hospitalization time. Thus, although more expensive initially, MRgFUS can decrease overall patient care cost [17]. In any case, direct comparison of safety and efficacy between MRgFUS and USgFUS is not possible since USgFUS was used mainly for primary malignant tumors whereas MRgFUS was used for benign and metastatic tumors. The only study on bone metastases was a subset from Li et al. [33] which did not show significant differences in terms of adverse events and response rates.

\section{Future directions}

The success of FUS ablation in the clinical studies summarized above demonstrates the promise of image-guided FUS and suggests further investigation is needed in larger numbers of patients with primary and secondary bone tumors. Three clinical trials are currently recruiting to evaluate MRgFUS in pain palliation of bone metastases: NCT01833806, NCT01964677 and NCT01586273. Other aspects could be addressed such as the correlation between site of metastases or primary tumor type and treatment outcome, local effect on the progression of bone metastases, long-term durability of pain palliation, and long-term durability of bone strength. Furthermore, the low procedure morbidity and short treatment time suggests that MRgFUS may also be a viable treatment option for patients with multifocal bone metastases. As pointed out by Gianfelice and his colleagues [20], treatment for multifocal disease can be repeated with no obvious increase in treatment morbidity. Expansion of indications for FUS inclusive of spinal treatments whether invasive [56] or non-invasive will significantly expand the number of patients 
that may benefit from this treatment modality. Finally, additional randomized studies for malignant lesions using multimodality approaches including FUS are warranted. 


\section{CONCLUSIONS}

Focused ultrasound is a treatment modality with both emerging and established roles in treatment of bone tumors. While most research has focused on MR guidance, both MR and US guidance have been studied with promising results. As phase III trials are yet to be completed for treatment of primary tumors, further study is warranted, particularly for primary malignant tumors, before FUS can be considered standard of care across all clinical applications related to bone lesions. Comprehensive review of studies to date, however, indicates that use of FUS to treat primary benign tumors, primary malignant tumors, and metastatic tumors is both safe and effective.

\section{Acknowledgements}

David Vrba acknowledges the EU project COST action TD1301 and the Czech Scientific Foundation, project 13-29857P. 
Table I. Thermal ablation techniques for bone cancer treatement.

\begin{tabular}{|c|c|c|c|c|c|c|}
\hline Bone Tumor & USgFUS & MRgFUS & RFA & MWA & Laser ablation & Cryoablation \\
\hline $\begin{array}{c}\text { Primary malignant } \\
\text { osteosarcoma }\end{array}$ & {$[19,33,34,46]$} & - & - & {$[57]$} & {$[58]$} & - \\
\hline $\begin{array}{c}\text { Other primary } \\
\text { malignant tumors }\end{array}$ & {$[19,33,34,46]$} & {$[5,19,33,46,49]$} & {$[59]$} & {$[60]$} & - & {$[61]$} \\
\hline $\begin{array}{c}\text { Primary benign } \\
\text { osteoid osteoma }\end{array}$ & - & {$[17,48,50]$} & {$[62,63]$} & {$[64]$} & {$[65]$} & {$[66]$} \\
\hline $\begin{array}{c}\text { Other primary } \\
\text { benign tumors }\end{array}$ & - & {$[67]$} & {$[68-71]$} & {$[72]$} & - & {$[73]$} \\
\hline Bone metastasis & {$[33]$} & {$[16,18,20,21,36,43,53-55]$} & {$[74,75]$} & {$[76]$} & - & {$[77]$} \\
\hline
\end{tabular}

Abbreviations for Tables II-IV: MR, magnetic resonance; US, ultrasound; IBMCWP, International Bone Metastasis Consensus Working Party; VAS, Visual Analogue Scale; VRS, Verbal Rating Scale; NRS, Numeric Rating Scale; QoL, Quality of Life; BPI, Brief Pain Inventory; MDA criteria, MD Anderson criteria; OR, overall response; CR, complete response; PR, partial response; PP, pain progression; NR, no response; RR, recurrence; AE, adverse event; SR, survival rate.

Table II. Clinical studies of image-guided FUS for primary benign bone tumors.

\begin{tabular}{|c|c|c|c|c|c|c|c|}
\hline Study & Patients & Primary Tumor & Endpoints & $\begin{array}{l}\text { Device + } \\
\text { Guidance }\end{array}$ & Follow-up & $\begin{array}{l}\text { Outcome } \\
\text { assessment }\end{array}$ & $\begin{array}{l}\text { Outcome }(a=\text { average, } m= \\
\text { months, } y=\text { years })\end{array}$ \\
\hline $\begin{array}{l}\text { Napoli } \\
2014[48] \\
\text { Geiger } \\
2014[17]\end{array}$ & 29 & Osteoid osteoma & $\begin{array}{l}\text { Palliation, } \\
\text { Efficacy, } \\
\text { Safety, }\end{array}$ & $\begin{array}{l}\text { ExAblate } \\
+\mathrm{MR}\end{array}$ & $\begin{array}{l}1,6,12,24 \\
\text { months }\end{array}$ & $\begin{array}{l}\text { IBMCWP } \\
\text { guidelines, } \\
\text { Imaging }\end{array}$ & $\begin{array}{l}\text { 93\% CR, 7\% PP }(12-24 \mathrm{~m}) \\
\text { aVAS }=7.9 \rightarrow 0.7(12-24 \mathrm{~m}) \\
0 \% \text { AE }(24 \mathrm{~m})\end{array}$ \\
\hline $\begin{array}{l}\text { Arrigoni } \\
2014[49]\end{array}$ & 12 & $\begin{array}{l}\text { Fibro-osteitis (7) } \\
\text { Periosteal } \\
\text { chondroma (2) } \\
\text { Others (3) }\end{array}$ & $\begin{array}{l}\text { Palliation, } \\
\text { Efficacy }\end{array}$ & $\begin{array}{l}\text { ExAblate } \\
+\mathrm{MR}\end{array}$ & $\begin{array}{l}6,12 \\
\text { months }\end{array}$ & $\begin{array}{l}\text { VAS, } \\
\text { Imaging }\end{array}$ & $\begin{array}{l}92 \% \text { OR, } 8 \% \text { NR, } 0 \% \text { PP }(12 \mathrm{~m}) \\
\text { aVAS }=7.8 \rightarrow 2.1(12 \mathrm{~m}) \\
\text { AE: } 66 \% \text { minor, } 0 \% \text { major } \\
(12 \mathrm{~m})\end{array}$ \\
\hline $\begin{array}{l}\text { Bazzocchi } \\
2014[50]\end{array}$ & 7 & Osteoid osteoma & $\begin{array}{l}\text { Palliation, } \\
\text { Safety, } \\
\text { QoL }\end{array}$ & $\begin{array}{l}\text { ExAblate } \\
+\mathrm{MR}\end{array}$ & $\begin{array}{l}1,3,6,12 \\
\text { months }\end{array}$ & VAS, QoL & $\begin{array}{l}86 \% \text { CR, } 14 \% \text { PR, 0\% PP }(1- \\
12 \mathrm{~m}) \\
\text { aVAS }=7.5 \rightarrow 0.3(1-12 \mathrm{~m}) \\
0 \% \text { AE }(1-12 \mathrm{~m})\end{array}$ \\
\hline
\end{tabular}


Table III. Clinical studies of image-guided FUS for primary malignant bone tumors.

\begin{tabular}{|c|c|c|c|c|c|c|c|}
\hline Study & Patients & Primary Tumor & Endpoints & $\begin{array}{l}\text { Device + } \\
\text { Guidance }\end{array}$ & Follow-up & $\begin{array}{l}\text { Outcome } \\
\text { assessment }\end{array}$ & $\begin{array}{l}\text { Outcome }(a=\text { average, } m= \\
\text { months, } y=\text { years })\end{array}$ \\
\hline $\begin{array}{l}\text { Wu } 2004 \\
{[34]}\end{array}$ & 44 & $\begin{array}{l}\text { Malignant (44) } \\
\text { Stage IIb (34) } \\
\text { Stage IIIb (10) }\end{array}$ & $\begin{array}{l}\text { Palliation } \\
\text { (Stage IIIb), } \\
\text { Limb } \\
\text { conservation } \\
\text { (Stage IIb), } \\
\text { Safety, } \\
\text { Survival } \\
\end{array}$ & $\begin{array}{l}\text { JC Haifu + } \\
\text { US }\end{array}$ & $\begin{array}{l}\text { 10-39 } \\
\text { months }\end{array}$ & $\begin{array}{l}\text { Kaplan-Meier } \\
\text { method, } \\
\text { Biochemical } \\
\text { analysis, } \\
\text { Amputation } \\
\text { rate, AE }\end{array}$ & $\begin{array}{l}\text { 11\% RR (lead to amputations) } \\
\text { AE: } 45 \% \text { minor, } 8 \% \text { major }(1-12 \mathrm{~m}) \\
\text { SR: } 85 \%(10-39 \mathrm{~m})\end{array}$ \\
\hline $\begin{array}{l}\mathrm{Li} 2010 \\
{[33]}\end{array}$ & 13 & $\begin{array}{l}\text { Osteosarcoma (12) } \\
\text { Fibrous Histiocytoma } \\
\text { (1) }\end{array}$ & $\begin{array}{l}\text { Palliation, } \\
\text { Safety, } \\
\text { Survival }\end{array}$ & $\begin{array}{l}\text { JC Haifu + } \\
\text { US }\end{array}$ & $\begin{array}{l}1,4,6 \\
\text { weeks, } 4 \\
, 6 \text { months }\end{array}$ & $\begin{array}{l}\text { VRS, AE, } \\
\text { Imaging, } \\
\text { Biochemical } \\
\text { analysis }\end{array}$ & $\begin{array}{l}85 \% \text { OR, } 8 \% \text { RR }(4-6 \mathrm{~m}) \\
46 \% \text { CR, 39\% PR }(4-6 \mathrm{~m}) \\
\text { aVRS } 1.85 \rightarrow 0.08(4-6 \mathrm{~m}) \\
\text { AE: } 68 \% \text { minor, } 0 \% \text { major }(4-6 \mathrm{~m}) \\
\text { SR: } 100 \%(1 \mathrm{y}), 85 \%(2 \mathrm{y}), 69 \% \\
(3 \mathrm{y}), 39 \%(5 \mathrm{y})\end{array}$ \\
\hline $\begin{array}{l}\text { Chen } \\
2010[19]\end{array}$ & 80 & $\begin{array}{l}\text { Osteosarcoma (63) } \\
\text { Other sarcomas } \\
\text { (13) } \\
\text { Others (4) }\end{array}$ & $\begin{array}{l}\text { Efficacy, } \\
\text { Safety, } \\
\text { Survival }\end{array}$ & $\begin{array}{l}\text { JC Haifu } \\
+ \text { US }\end{array}$ & $\begin{array}{l}1,2,3,4,5 \\
\text { years }\end{array}$ & $\begin{array}{l}\text { Kaplan-Meier } \\
\text { method, } \\
\text { Imaging, } \\
\text { Blood } \\
\text { analysis, AE } \\
\end{array}$ & $\begin{array}{l}86 \% \text { CR, } 14 \% \text { NR }(2-8 \mathrm{w}) \\
6 \% \text { RR }(2 \mathrm{y}), 12 \% \text { RR }(5 \mathrm{y}) \\
\text { AE: } 100 \% \text { minor, } 28 \% \text { major }(5 \mathrm{y}) \\
\text { SR: } 90 \%(1 \mathrm{y}), 72 \%(2 \mathrm{y}), 61 \%(3 \mathrm{y}) \\
51 \%(4 \mathrm{y}) \text { and } 51 \%(5 \mathrm{y})\end{array}$ \\
\hline $\begin{array}{l}\text { Wang } \\
2013[46]\end{array}$ & 11 & $\begin{array}{l}\text { Osteosarcoma (4) } \\
\text { Ewing's sarcoma (2) } \\
\text { Chondrosarcoma (2) } \\
\text { Others (3) }\end{array}$ & $\begin{array}{l}\text { Palliation, } \\
\text { Local tumor } \\
\text { control }\end{array}$ & $\begin{array}{l}\text { JC Haifu } \\
+ \text { US }\end{array}$ & $\begin{array}{l}1,3,6 \\
\text { every } 6 \\
\text { months }\end{array}$ & Imaging & $\begin{array}{l}87 \% \text { OR }(1 \mathrm{~d}), 0 \% \mathrm{RR} \text { and } 0 \% \mathrm{PP} \text { at } \\
\text { the time of publication } \\
\text { AE: } 100 \% \text { minor, } 0 \% \text { major }\end{array}$ \\
\hline
\end{tabular}


Table IV. Clinical studies of image-guided FUS for painful bone metastases.

\begin{tabular}{|c|c|c|c|c|c|c|c|}
\hline Study & $\begin{array}{l}\text { Patients } \\
\text { (lesions) }\end{array}$ & $\begin{array}{l}\text { Primary } \\
\text { Tumor }\end{array}$ & Endpoints & $\begin{array}{l}\text { Device + } \\
\text { Guidance }\end{array}$ & Follow-up & $\begin{array}{l}\text { Outcome } \\
\text { assessment }\end{array}$ & $\begin{array}{l}\text { Outcome }(a=\text { average } \mathrm{VAS}, \mathrm{m}=\text { months, } \\
\mathrm{y}=\text { years })\end{array}$ \\
\hline $\begin{array}{l}\text { Liberman } \\
2009[21]\end{array}$ & $31(32)$ & $\begin{array}{l}\text { Breast (11) } \\
\text { Kidneys (6) } \\
\text { Prostate (5) } \\
\text { Others (9) }\end{array}$ & $\begin{array}{l}\text { Palliation, } \\
\text { Safety }\end{array}$ & $\begin{array}{l}\text { ExAblate } \\
+ \text { MR }\end{array}$ & $\begin{array}{l}3 \text { days, } \\
2 \text { weeks, } \\
1,3,6 \\
\text { months }\end{array}$ & $\begin{array}{l}\text { IBMCWP } \\
\text { guidelines }\end{array}$ & $\begin{array}{l}72 \% \text { OR, } 4 \% \text { PP }(3 \mathrm{~m}) \\
36 \% \text { CR, 36\% PR, 24\% NR }(3 \mathrm{~m}) \\
\text { aVAS }=5.9 \rightarrow 1.8(3 \mathrm{~m}) \\
\text { AE: } 0 \%(3 \mathrm{~m})\end{array}$ \\
\hline $\begin{array}{l}\mathrm{Li} 2010 \\
{[33]}\end{array}$ & 12 & $\begin{array}{l}\text { Liver (5) } \\
\text { Lung (4) } \\
\text { Kidney (1) } \\
\text { Others (2) }\end{array}$ & $\begin{array}{l}\text { Palliation, } \\
\text { Safety, } \\
\text { Survival }\end{array}$ & $\begin{array}{l}\text { JC Haifu } \\
+ \text { US }\end{array}$ & $\begin{array}{l}1,4,6 \\
\text { weeks, } \\
\text { 4, } 6 \text { months }\end{array}$ & $\begin{array}{l}\text { VRS, } \\
\text { Imaging, } \\
\text { Biochemica } \\
1 \text { analysis }\end{array}$ & $\begin{array}{l}75 \% \text { OR, } 8 \% \text { PP }(4-6 \mathrm{~m}) \\
42 \% \text { CR, 33\% PR }(4-6 \mathrm{~m}) \\
\text { aVRS }=1.75 \rightarrow 0.17(4-6 \mathrm{~m}) \\
\text { SR: } 83 \%(1 \mathrm{y}), 17 \%(2 \mathrm{y}), 0 \%(3 \mathrm{y}) \\
\text { AE: } 68 \% \text { minor, } 0 \% \text { major }(4-6 \mathrm{~m})\end{array}$ \\
\hline $\begin{array}{l}\text { Napoli } \\
2013[37]\end{array}$ & 18 & $\begin{array}{l}\text { Lung (5) } \\
\text { Breast (4) } \\
\text { Kidney (3) } \\
\text { Others (6) }\end{array}$ & $\begin{array}{l}\text { Palliation, } \\
\text { Local tumor } \\
\text { control }\end{array}$ & $\begin{array}{l}\text { ExAblate } \\
+ \text { MR }\end{array}$ & $\begin{array}{l}1,3,6 \\
\text { months }\end{array}$ & $\begin{array}{l}\text { IBMCWP } \\
\text { guidelines, } \\
\text { BPI, MDA } \\
\text { criteria }\end{array}$ & $\begin{array}{l}89 \% \text { OR }(3 \mathrm{~m}) \\
72 \% \text { CR, } 17 \% \text { PR, } 11 \% \text { PP }(3 \mathrm{~m}) \\
\text { aVAS }=7.1 \rightarrow 1.0(3 \mathrm{~m}) \\
\text { AE: } 0 \%(3 \mathrm{~m})\end{array}$ \\
\hline $\begin{array}{l}\text { Hurwitz } \\
2014[43]\end{array}$ & 112 & $\begin{array}{l}\text { Breast (34) } \\
\text { Lung (17) } \\
\text { Prostate (15) } \\
\text { Others (44) } \\
\end{array}$ & $\begin{array}{l}\text { Palliation, } \\
\text { Safety, QoL }\end{array}$ & $\begin{array}{l}\text { ExAblate } \\
+\mathrm{MR}\end{array}$ & $\begin{array}{l}2,5,7,14 \\
30,60,180 \\
\text { days }\end{array}$ & $\begin{array}{l}\text { IBMCWP } \\
\text { guidelines, } \\
\text { BPI }\end{array}$ & $\begin{array}{l}64 \% \text { OR, } 23 \% \text { CR }(3 \mathrm{~m}) \\
\text { aNRS reduced } 3.6 \text { points }(3 \mathrm{~m}) \\
\text { AE: } 51 \% \text { minor, } 4 \% \text { major }(3 \mathrm{~m}) \\
60 \% \text { of AEs solved in } 1 \mathrm{~d}\end{array}$ \\
\hline $\begin{array}{l}\text { Huisman } \\
2014[51]\end{array}$ & $11(12)$ & $\begin{array}{l}\text { Kidney (3) } \\
\text { Colorectal (3) } \\
\text { Breast (2) } \\
\text { Others (3) }\end{array}$ & $\begin{array}{l}\text { Safety, } \\
\text { Efficacy, } \\
\text { Technical } \\
\text { feasibility }\end{array}$ & $\begin{array}{l}\text { Sonnallev } \\
\text { e+MR }\end{array}$ & $\begin{array}{l}3 \text { days, } \\
1 \text { month }\end{array}$ & $\begin{array}{l}\text { IBMCWP } \\
\text { guidelines }\end{array}$ & $\begin{array}{l}67 \% \text { OR }(1 \mathrm{~m}) \\
11 \% \text { CR, } 56 \% \text { PR, } 0 \% \text { PP }(1 \mathrm{~m}) \\
\text { aVAS }=8 \rightarrow 4(1 \mathrm{~m}) \\
\text { AE: } 18 \% \text { minor, } 0 \% \text { major }(1 \mathrm{~m})\end{array}$ \\
\hline $\begin{array}{l}\text { Meyer } 2014 \\
{[53]}\end{array}$ & 104 & $\begin{array}{l}\text { Subset from } \\
\text { Hurwitz et } \\
\text { al, } 2014\end{array}$ & $\begin{array}{l}\text { Efficacy, } \\
\text { Safety }\end{array}$ & $\begin{array}{l}\text { ExAblate } \\
+\mathrm{MR}\end{array}$ & 3 months & $\begin{array}{l}\text { IBMCWP } \\
\text { guidelines, } \\
\text { BPI }\end{array}$ & $\begin{array}{l}\text { Responders, AE, Sonication pain: } \\
68 \%, 45 \%, 28 \% \text { (FUS) } \\
71 \%, 57 \%, 50 \% \text { (FUS+chemo) }\end{array}$ \\
\hline $\begin{array}{l}\text { Zaccagna } \\
2014[54]\end{array}$ & $72(87)$ & Not provided & $\begin{array}{l}\text { Palliation, } \\
\text { QoL }\end{array}$ & $\begin{array}{l}\text { ExAblate } \\
+ \text { MR }\end{array}$ & $\begin{array}{l}1,36 \\
\text { months }\end{array}$ & $\begin{array}{l}\text { IBMCWP } \\
\text { guidelines, } \\
\text { QLQ-BM22 }\end{array}$ & $\begin{array}{l}47 \% \text { CR, } 40 \% \text { PR, } 13 \% \text { PP }(6 \mathrm{~m}) \\
\text { aVAS }=6 \rightarrow 2(6 \mathrm{~m}) \\
\text { AE: } 0 \%(6 \mathrm{~m})\end{array}$ \\
\hline $\begin{array}{l}\text { Bazzocchi } \\
2014 \text { [55] }\end{array}$ & $39(57)$ & $\begin{array}{l}\text { Breast (15) } \\
\text { Kidney (5) } \\
\text { Others (18) } \\
\end{array}$ & $\begin{array}{l}\text { Palliation, } \\
\text { Safety, QoL }\end{array}$ & $\begin{array}{l}\text { ExAblate } \\
+\mathrm{MR}\end{array}$ & $\begin{array}{l}1,3,6,12 \\
\text { months }\end{array}$ & $\begin{array}{l}\text { VAS } \\
\mathrm{AE}\end{array}$ & $\begin{array}{l}\text { aVAS }=5.2 \rightarrow 1.2(12 \mathrm{~m}) \\
\text { VAS }=0(1 \mathrm{~m}) \text { in } 31 \% \text { patients } \\
\text { AE: } 5 \% \text { minor, } 0 \% \text { major }(12 \mathrm{~m})\end{array}$ \\
\hline
\end{tabular}




\section{REFERENCES}

1. Kindblom LG. Bone tumors: Epidemiology, classification, pathology. Imaging of Bone Tumors and Tumor-Like Lesions: Techniques and Applications. 2009:1-15.

2. Greenspan A. Benign bone-forming lesions - osteoma, osteoid osteoma, and osteoblastoma clinical, imaging, pathological, and differential considerations. Skeletal Radiol. 1993;22(7):485-500.

3. Crist BD, Lenke LG, Lewis S. Osteoid osteoma of the lumbar spine - a case report highlighting a novel reconstruction technique. J Bone Joint Surg Am. 2005;87A(2):414-8.

4. Rosenthal D, Callstrom MR. Critical review and state of the art in interventional oncology: Benign and metastatic disease involving bone. Radiology. 2012;262(3):765-80.

5. Masciocchi C, Conchiglia A, Gregori LM, Arrigoni F, Zugaro L, Barile A. Critical role of HIFU in musculoskeletal interventions. Radiol Med. 2014;119(7):470-5.

6. Franchi A. Epidemiology and classification of bone tumors. Clin Cases Miner Bone Metab. 2012;9(2):92-5.

7. Berenson JR, Rajdev L, Broder M. Pathophysiology of bone metastases. Cancer Biol Ther. 2006;5(9):1078-81.

8. Nielsen OS, Munro AJ, Tannock IF. Bone metastases - Pathophysiology and management policy. J Clin Oncol. 1991;9(3):509-24.

9. Roodman GD. Mechanisms of disease: Mechanisms of bone metastasis. N Engl J Med. 2004;350(16):1655-64.

10. Gangi A, Tsoumakidou G, Buy X, Quoix E. Quality improvement guidelines for bone tumour management. Cardiovasc Intervent Radiol. 2010;33(4):706-13.

11. Stauffer PR. Techniques for interstitial hyperthermia. In: Field SB, Hand JW, editors. An introduction to the practical aspects of clinical hyperthermia. London, New York: Taylor \& Francis; 1990. p. 344-70.

12. Stauffer PR, Diederich CJ, Seegenschmiedt MH. Interstitial heating technologies. In: Seegenschmiedt MH, Fessenden P, Vernon CC, editors. Thermoradiotherapy and thermochemotherapy: Volume 1, Biology, Physiology and Physics. Berlin, New York: Springer-Verlag; 1995. p. 279-320.

13. Skinner MG, Iizuka MN, Kolios MC, Sherar MD. A theoretical comparison of energy sources-microwave, ultrasound and laser-for interstitial thermal therapy. Phys Med Biol. 1998;43(12):3535-47.

14. Strohbehn JW. Interstitial techniques for hyperthermia. In: Field SB, Franconi C, editors. Physics and technology of hyperthermia. Dordrecht, Boston, Lancaster: Martinus Nijhoff Publishers; 1987. p. 211-40.

15. Ahmed M, Brace CL, Lee FT, Jr., Goldberg SN. Principles of and advances in percutaneous ablation. Radiology. 2011;258(2):351-69.

16. Napoli A, Anzidei M, Marincola BC, Brachetti G, Noce V, Boni F, et al. MR imagingguided focused ultrasound for treatment of bone metastasis. Radiographics. 2013;33(6):1555-68.

17. Geiger D, Napoli A, Conchiglia A, Gregori LM, Arrigoni F, Bazzocchi A, et al. MR-guided focused ultrasound (MRgFUS) ablation for the treatment of nonspinal osteoid osteoma. $J$ Bone Joint Surg Am. 2014;96A(9):743-51.

18. Catane R, Beck A, Inbar Y, Rabin T, Shabshin N, Hengst S, et al. MR-guided focused ultrasound surgery (MRgFUS) for the palliation of pain in patients with bone metastases preliminary clinical experience. Ann Oncol. 2007;18(1):163-7. 
19. Chen WZ, Zhu H, Zhang L, Li KQ, Su HB, Jin CB, et al. Primary bone malignancy: Effective treatment with high-intensity focused ultrasound ablation. Radiology. 2010;255(3):967-78.

20. Gianfelice D, Gupta C, Kucharczyk W, Bret P, Havill D, Clemons M. Palliative treatment of painful bone metastases with MR imaging-guided focused ultrasound. Radiology. 2008;249(1):355-63.

21. Liberman B, Gianfelice D, Inbar Y, Beck A, Rabin T, Shabshin N, et al. Pain palliation in patients with bone metastases using MR-guided focused ultrasound surgery: A multicenter study. Ann Surg Oncol. 2009;16(1):140-6.

22. Ebbini ES, Cain CA. A spherical-section ultrasound phased array applicator for deep localized hyperthermia. IEEE Trans Biomed Eng. 1991;38(7):634-43.

23. Ebbini ES, Cain CA. Experimental evaluation of a prototype cylindrical section ultrasound hyperthermia phased array applicator. IEEE Trans Ultrason Ferroelectr Freq Control. 1991;38:510-20.

24. Hynynen K, Shimm D, Anhalt D, Stea B, Sykes H, Cassady JR, et al. Temperature distributions during clinical scanned, focused ultrasound hyperthermia treatments. Int $\mathbf{J}$ Hyperthermia. 1990;6(5):891-908.

25. Hynynen K, Clement GT, McDannold N, Vykhodtseva N, King R, White PJ, et al. 500element ultrasound phased array system for noninvasive focal surgery of the brain: A preliminary rabbit study with ex vivo human skulls. Magn Reson Med. 2004;52(1):100-7.

26. Marmor JB, Pounds D, Postic TB, Hahn GM. Treatment of superficial human neoplasms by local hyperthermia induced by ultrasound. Cancer. 1979;43:188-97.

27. Chen D, Xia R, Chen X, Shafirstein G, Corry PM, Griffin RJ, et al. Sonoknife: Feasibility of a line-focused ultrasound device for thermal ablation therapy. Med Phys. 2011;38(7):437285.

28. Chopra R, Curiel L, Staruch R, Morrison L, Hynynen K. An MRI-compatible system for focused ultrasound experiments in small animal models. Med Phys. 2009;36(5):1867-74.

29. Dick EA, Gedroyc WM. Exablate magnetic resonance-guided focused ultrasound system in multiple body applications. Expert Rev Med Devices. 2010;7(5):589-97.

30. O'Neill BE, Karmonik C, Li KC. An optimum method for pulsed high intensity focused ultrasound treatment of large volumes using the Insightec Exablate ${ }^{\circledR} 2000$ system. Phys Med Biol. 2010;55(21):6395-410.

31. Dorenberg EJ, Courivaud F, Ring E, Hald K, Jakobsen JA, Fosse E, et al. Volumetric ablation of uterine fibroids using sonalleve high-intensity focused ultrasound in a 3 tesla scanner-first clinical assessment. Minim Invasive Ther Allied Technol. 2013;22(2):73-9.

32. Venkatesan AM, Partanen A, Pulanic TK, Dreher MR, Fischer J, Zurawin RK, et al. Magnetic resonance imaging-guided volumetric ablation of symptomatic leiomyomata: Correlation of imaging with histology. J Vasc Interv Radiol. 2012;23(6):786-94.

33. Li CX, Zhang WD, Fan WJ, Huang JH, Zhang FJ, Wu PH. Noninvasive treatment of malignant bone tumors using high-intensity focused ultrasound. Cancer. 2010;116(16):393442.

34. Wu F, Wang ZB, Chen WZ, Zou JZ, Bai J, Zhu H, et al. Extracorporeal focused ultrasound surgery for treatment of human solid carcinomas: Early chinese clinical experience. Ultrasound Med Biol. 2004;30(2):245-60.

35. Orgera G, Monfardini L, Della Vigna P, Zhang L, Bonomo G, Arnone P, et al. Highintensity focused ultrasound (HIFU) in patients with solid malignancies: Evaluation of feasibility, local tumour response and clinical results. Radiol Med. 2011;116(5):734-48. 
36. Catane R, Gianfelice D, Kawasaki M, Iozeffi D, Kanyev S, Napoli A, et al. Pain palliation of bone metastases using magnetic resonance guided focused ultrasound - Multi-center multitrial results. Ann Oncol. 2012;23:463.

37. Napoli A, Anzidei M, Marincola BC, Brachetti G, Ciolina F, Cartocci G, et al. Primary pain palliation and local tumor control in bone metastases treated with magnetic resonance-guided focused ultrasound. Invest Radiol. 2013;48(6):351-8.

38. Mor V, Laliberte L, Morris JN, Wiemann M. The karnofsky performance status scale. An examination of its reliability and validity in a research setting. Cancer. 1984;53(9):2002-7.

39. Sacks D, McClenny TE, Cardella JF, Lewis CA. Society of interventional radiology clinical practice guidelines. J Vasc Interv Radiol. 2003;14(9 Pt 2):S199-202.

40. Goldberg SN, Grassi CJ, Cardella JF, Charboneau JW, Dodd GD, III, Dupuy DE, et al. Image-guided tumor ablation: Standardization of terminology and reporting criteria. J Vasc Interv Radiol. 2009;20(7):S377-S90.

41. Costelloe CM, Chuang HH, Madewell JE, Ueno NT. Cancer response criteria and bone metastases: Recist 1.1, mda and percist. J Cancer. 2010;1:80-92.

42. Cleeland CS, Ryan KM. Pain assessment: Global use of the brief pain inventory. Ann Acad Med Singapore. 1994;23(2):129-38.

43. Hurwitz MD, Ghanouni P, Kanaev SV, Iozeffi D, Gianfelice D, Fennessy FM, et al. Magnetic resonance-guided focused ultrasound for patients with painful bone metastases: Phase III trial results. J Natl Cancer Inst. 2014;106(5).

44. Chow E, Wu JSY, Hoskin P, Coia LR, Bentzen SM, Blitzer PH, et al. International consensus on palliative radiotherapy endpoints for future clinical trials in bone metastases. Radiother Oncol. 2002;64(3):275-80.

45. Chow E, Hird A, Velikova G, Johnson C, Dewolf L, Bezjak A, et al. The European Organisation for research and treatment of cancer quality of life questionnaire for patients with bone metastases: The EORTC QLQ-BM22. Eur J Cancer. 2009;45(7):1146-52.

46. Wang Y, Wang W, Tang J. Primary malignant tumours of the bony pelvis: US-guided high intensity focused ultrasound ablation. Int J Hyperthermia. 2013;29(7):683-7.

47. Napoli A, Mastantuono M, Marincola BC, Anzidei M, Zaccagna F, Moreschini O, et al. Osteoid osteoma: MR-guided focused ultrasound for entirely noninvasive treatment. Radiology. 2013;267(2):514-21.

48. Napoli A, Zaccagna F, Cartocci G, Giulia B, Caliolo G, Andrani F, et al. Magnetic resonance guided focused ultrasound surgery (MRgFUS) treatment of osteoid osteoma: A prospective development study. Focused Ultrasound 2014; Bethesda, MA USA 2014. p. 44-BN.

49. Arrigoni F, Gregori LM, La Marra A, Conchiglia A, Zugaro L, Barile A, et al. Our experience of non-invasive treatment of epiphyseal benign bone lesions using MRgFUS: Can it really be a definitive solution? European Society of Radiology 2014; Vienna, Austria 2014. p. B-0263, 9 .

50. Bazzocchi A, Napoli A, Filonzi G, Facchini G, Spinnato P, Busacca M, et al. MRgFUS treatment of superficial osteoid osteomas of the lower limbs. Focused Ultrasound 2014; Bethesda, MA USA 2014. p. 45-BN.

51. Huisman M, Lam MK, Bartels LW, Nijenhuis RJ, Moonen CT, Knuttel FM, et al. Feasibility of volumetric MRI-guided high intensity focused ultrasound (MF-HIFU) for painful bone metastases. J Ther Ultrasound. 2014;2:16.

52. Köhler MO, Mougenot C, Quesson B, Enholm J, Le Bail B, Laurent C, et al. Volumetric HIFU ablation under 3D guidance of rapid MRI thermometry. Med Phys. 2009;36(8):352135 . 
53. Meyer J, Pfeffer R, Kanaev S, Iozeffi D, Gianfelice D, Ghanouni P, et al. MR-guided focused ultrasound for painful bone metastases: Safety when combined with chemotherapy. Focused Ultrasound 2014; Bethesda, MA USA 2014. p. 50-BM.

54. Zaccagna F, Giulia B, Bazzocchi A, Spinnato P, Albisinni U, Napoli A, et al. Palliative treatment of painful bone metastases with MR imaging-guided focused ultrasound surgery: A two-centre study. Focused Ultrasound 2014; Bethesda, MA USA 2014. p. 51-BM.

55. Bazzocchi A, Napoli A, Filonzi G, Spinnato P, Colangeli M, Battaglia M, et al. Palliation of painful bone metastases: The "Rizzoli" experience. Focused Ultrasound 2014; Bethesda, MA USA 2014. p. 52-BM.

56. Scott SJ, Salgaonkar V, Prakash P, Burdette EC, Diederich CJ. Interstitial ultrasound ablation of vertebral and paraspinal tumours: Parametric and patient-specific simulations. Int J Hyperthermia. 2014;30(4):228-44.

57. Yu Z, Geng J, Zhang M, Zhou Y, Fan Q, Chen J. Treatment of osteosarcoma with microwave thermal ablation to induce immunogenic cell death. Oncotarget. 2014;5(15):14.

58. Gebauer B, Tunn P. Thermal ablation in bone tumors. Recent Results Cancer Res. 2006:13546.

59. Rosenthal DI, Treat ME, Mankin HJ, Rosenberg AE, Jennings CL. Treatment of epithelioid hemangioendothelioma of bone using a novel combined approach. Skeletal Radiology. 2001;30(4):219-22.

60. Lu S, Wang J, Hu Y. [Microwave heating and neoadjuvant chemotherapy for malignant bone tumor]. Zhonghua Wai Ke Za Zhi. 1997;35(4):196-9.

61. Kurup AN, Woodrum DA, Morris JM, Atwell TD, Schmit GD, Welch TJ, et al. Cryoablation of recurrent sacrococcygeal tumors. J Vasc Interv Radiol. 2012;23(8):1070-5.

62. Mahnken AH, Tacke JA, Wildberger JE, Gunther RW. Radiofrequency ablation of osteoid osteoma: Initial results with a bipolar ablation device. J Vasc Interv Radiol. 2006;17(9):1465 -70 .

63. Mahnken AH, Bruners P, Delbruuck H, Gunther RW. Radiofrequency ablation of osteoid osteoma: Initial experience with a new monopolar ablation device. Cardiovasc Intervent Radiol. 2011;34(3):579-84.

64. Basile A, Failla G, Reforgiato A, Scavone G, Mundo E, Messina M, et al. The use of microwaves ablation in the treatment of epiphyseal osteoid osteomas. Cardiovasc Intervent Radiol. 2014;37(3):737-42.

65. Gangi A, Alizadeh H, Wong L, Buy X, Dietemann JL, Roy C. Osteoid osteoma: Percutaneous laser ablation and follow-up in 114 patients. Radiology. 2007;242(1):293-301.

66. Coupal TM, Mallinson PI, Munk PL, Liu D, Clarkson P, Ouellette H. CT-guided percutaneous cryoablation for osteoid osteoma: Initial experience in adults. AJR Am J Roentgenol. 2014;202(5):1136-9.

67. Bazzocchi A, Napoli A, Filonzi G, Busacca M, Palmerini E, Ferrari S, et al. MRgFUS new applications in musculoskeletal pathology: A miscellaneous case review. Focused Ultrasound 2014; Bethesda, MA USA 2014. p. 46-BN.

68. Corby RR, Stacy GS, Peabody TD, Dixon LB. Radiofrequency ablation of solitary eosinophilic granuloma of bone. AJR Am J Roentgenol. 2008;190(6):1492-4.

69. Ramnath RR, Rosenthal DI, Cates J, Gebhardt M, Quinn RH. Intracortical chondroma simulating osteoid osteoma treated by radiofrequency. Skeletal Radiology. 2002;31(10):597602. 
70. Becce F, Richarme D, Letovanec I, Gilgien W, Theumann N. Percutaneous radiofrequency ablation of primary intraosseous spinal glomus tumor. Skeletal Radiology. 2012;41(4):46772.

71. Cable BB, Mair EA. Radiofrequency ablation of lymphangiomatous macroglossia. Laryngoscope. 2001;111(10):1859-61.

72. Fan QY, Ma BA, Qiu XC, Li YL, Ye J, Zhou Y. Preliminary report on treatment of bone tumors with microwave-induced hyperthermia. Bioelectromagnetics. 1996;17(3):218-22.

73. Tutton S, Olson E, King D, Shaker JL. Successful treatment of tumor-induced osteomalacia with CT-guided percutaneous ethanol and cryoablation. J Clin Endocrinol Metab. 2012; 97(10):3421-5.

74. Callstrom MR, Charboneau JW, Goetz MP, Rubin J, Wong GY, Sloan JA, et al. Painful metastases involving bone: Feasibility of percutaneous CT- and US-guided radio-frequency ablation. Radiology. 2002;224(1):87-97.

75. Carrafiello G, Lagana D, Pellegrino C, Fontana F, Mangini M, Nicotera P, et al. Percutaneous imaging-guided ablation therapies in the treatment of symptomatic bone metastases: Preliminary experience. Radiologia Medica. 2009;114(4):608-25.

76. Pusceddu C, Sotgia B, Fele RM, Melis L. Treatment of bone metastases with microwave thermal ablation. J Vasc Interv Radiol. 2013;24(2):229-33.

77. Callstrom MR, Dupuy DE, Solomon SB, Beres RA, Littrup PJ, Davis KW, et al. Percutaneous image-guided cryoablation of painful metastases involving bone multicenter trial. Cancer. 2013;119(5):1033-41. 